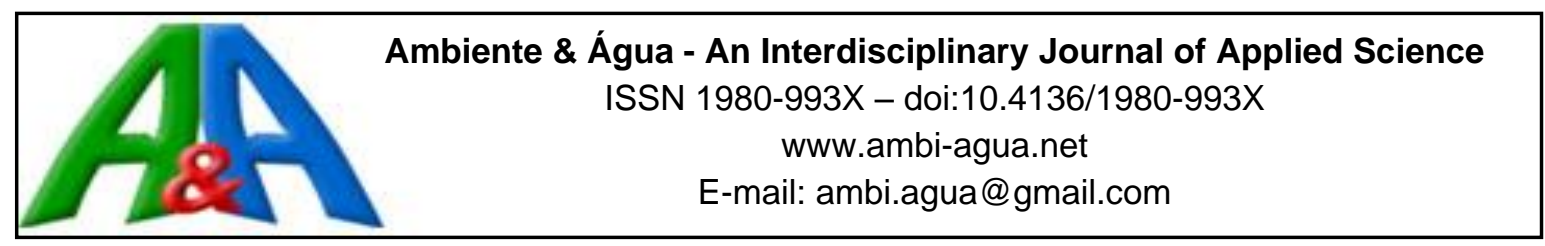

\title{
Activated carbon loaded with manganese and iron for glyphosate adsorption: Kinetics, isotherms and thermodynamic studies
}

\author{
ARTICLES doi:10.4136/ambi-agua.2414
}

Received: 17 May 2019; Accepted: 16 Oct. 2019

\begin{abstract}
Natalia Ueda Yamaguchi ${ }^{\text {*(D) }}$; Andressa Jenifer Rubio ${ }^{1}$ iD Rosângela Bergamasco $^{2}$ iD
${ }^{1}$ Instituto Cesumar de Ciência, Tecnologia e Inovação. Programa de Pós-graduação em Tecnologias Limpas. Centro Universitário de Maringá (Unicesumar), Avenida Guedner, n 1610, CEP: 87050-900, Maringá, PR, Brazil. E-mail: andressajrubio@gmail.com

${ }^{2}$ Departamento de Engenharia Química. Centro Universitário de Maringá (Unicesumar), Avenida Colombo, $\mathrm{n}^{\circ}$ 5790, CEP: 87020-900, Maringá, PR, Brazil. E-mail: ro.bergamasco@ hotmail.com *Corresponding author. E-mail: nataliaueda@ hotmail.com
\end{abstract}

\begin{abstract}
Granular activated carbon was loaded with $0.5 \%$ manganese and $1.0 \%$ iron $(\mathrm{m} / \mathrm{m})$ for glyphosate removal from aqueous solutions. The adsorbent material was characterized by scanning electron microscopy, dispersive energy spectrometry, nitrogen adsorption techniques and zeta potential analyses. Batch studies were performed to investigate the adsorption equilibrium, kinetics mechanisms and to obtain thermodynamic information. Glyphosate adsorption increased with the contact time and achieved equilibrium within $24 \mathrm{~h}$, with a maximum adsorption capacity of $9.19 \mathrm{mg} \mathrm{g}^{-1}$ at $45^{\circ} \mathrm{C}$. Batch kinetic experimental data obeyed the pseudo-second-order model with $\mathrm{R}^{2}>0.99$. Adsorption isotherm experiments were carried out at $5,15,25,35$ and $45^{\circ} \mathrm{C}$. The adsorption isotherms presented a better fitting using the Freundlich model $\left(\mathrm{R}^{2}>0.98\right)$, indicating a multilayer adsorption of glyphosate. Thermodynamics studies showed that the adsorption of glyphosate onto granular activated carbon loaded with manganese and iron was spontaneous and feasible with negative values of $\Delta \mathrm{G}^{\circ}$, endothermic with $\Delta \mathrm{H}^{\circ}$ of $20.924 \mathrm{~kJ} \mathrm{~mol}^{-1}$ and $\Delta \mathrm{S}^{\circ}$ of $-73.250 \mathrm{~J} \mathrm{~mol}^{-1} \mathrm{~K}^{-1}$, suggesting a decrease in randomness at the solid-liquid interface between glyphosate and the adsorbent. The experimental results demonstrated that activated carbon loaded with manganese and iron may be an alternative for glyphosate removal in water, wastewater treatment and purification processes.
\end{abstract}

Keywords: herbicide, impregnation, water treatment.

\section{Carvão ativado impregnado com manganês e ferro para adsorção de glifosato: Cinética, isotermas e estudos termodinâmicos}

\section{RESUMO}

Carvão ativado granular foi impregnado com $1 \%$ de ferro e $0,5 \%$ de manganês $(\mathrm{m} / \mathrm{m})$ para remoção de glifosato em soluções aquosas. $\mathrm{O}$ adsorvente foi caracterizado por microscopia eletrônica de varredura, espectroscopia de energia dispersiva, técnicas de adsorção de nitrogênio e análises de potencial zeta. Estudos em batelada foram realizados para investigar os mecanismos de equilíbrio, cinética de adsorção e informações termodinâmicas. Com relação ao tempo de contato e capacidade máxima de adsorção, a adsorção de glifosato aumentou com o 
tempo de contato e alcançou o equilíbrio em $24 \mathrm{~h}$, com uma capacidade máxima de adsorção de $9,19 \mathrm{mg} \mathrm{g}^{-1}$ a $45^{\circ} \mathrm{C}$. Os dados experimentais cinéticos em batelada foram ajustados ao modelo de pseudo-segunda ordem com $\mathrm{R}^{2}>0,99$. Experimentos de equilíbrio foram realizados a $5,15,25,35$ e $45^{\circ} \mathrm{C}$. As isotermas de adsorção ajustaram-se melhor usando o modelo de Freundlich $\left(\mathrm{R}^{2}>0,98\right)$, indicando uma adsorção multicamadas do glifosato. Estudos termodinâmicos mostraram que a adsorção de glifosato sobre carvão ativado granular impregnado com manganês e o ferro foi espontânea e viável $\left(\Delta \mathrm{G}^{\circ}<0\right)$, endotérmica $\left(\Delta \mathrm{H}^{\circ}=\right.$ $20.924 \mathrm{~kJ} \mathrm{~mol}^{-1}$ ) e com $\Delta \mathrm{S}^{\circ}$ de $-73,250 \mathrm{~J} \mathrm{~mol}^{-1} \mathrm{~K}^{-1}$, indicando uma diminuição da entropia do sistema na interface sólido-líquido durante o processo de adsorção do glifosato ao adsorvente.. Assim, o adsorvente desenvolvido neste trabalho mostrou-se uma alternativa para a remoção do glifosato em processos de tratamento e purificação de água.

Palavras-chave: herbicida, impregnação, tratamento de água.

\section{INTRODUCTION}

Glyphosate (N-(phosphonomethyl) glycine), an organophosphorus, is a broad-spectrum, nonselective, post-emergence herbicide, and it is one of the most-used on many crops and as well in non-agricultural areas, such as recreational fields (Waiman et al., 2012). Glyphosate was introduced into the market in 1974, and it is now responsible for approximately $60 \%$ of global herbicide sales worldwide (Battaglin et al., 2005).

Contamination of water by glyphosate has increased due to the large quantities used throughout the world (Hu et al., 2011). Its safety and impacts on the environment and on humans is of great concern, as many studies suggest the toxic effects of glyphosate (Hagner et al., 2013). Research shows possible endocrinal, mutagenic, carcinogenic, genotoxic and neurologic effects associated with the use of glyphosate (Myers et al., 2016). The United States Environmental Protection Agency sets maximum contaminant levels in drinking water at 0.7 $\mathrm{mg} \mathrm{L}^{-1}$; while the guidelines for Canadian drinking water allow a maximum of $0.28 \mathrm{mg} \mathrm{L}^{-1}$. It is therefore necessary to develop processes to remove glyphosate from water to within permissible limits.

Glyphosate removal from aqueous solutions include various methods, including adsorption, nanofiltration, advanced oxidation, oxidation technologies, electrochemical degradation, photocatalytic degradation and microbial degradation (Cui et al., 2012). Adsorption is recognized as one of the most effective and widely used techniques for the removal of pesticides from water. Adsorption of pesticides on solid substrates such as soils, clays, or activated carbon (AC) is one of the top technology for the remediation of pollutants, as it is low-cost, easy to operate, efficient and flexible (Ghaedi et al., 2014).

$\mathrm{AC}$ has received much attention as an efficient adsorbent for the removal of many agrochemicals and other synthetic contaminants in drinking water (Bhatnagar et al., 2013). It has been widely used as an adsorbent in the purification of aqueous media, gas/solid phase separation, catalysis, electrochemical processes, among others. Its surface characteristics, such as the extended range of porosity and high surface area, ease of separation, low operational cost and significant sorption affinity make $\mathrm{AC}$ a versatile and preferred material for various applications (Gupta et al., 2013; Shah et al., 2015).

$\mathrm{AC}$ is more efficient at removing organic components compared with removing other inorganic pollutants and metals. Therefore, it is mainly used for the removal of micropollutants and organic matter. In recent years, emphasis has been placed on preparing AC with modified surfaces using different procedures to improve the potential of $\mathrm{AC}$ for specific contaminants (Bhatnagar et al., 2013).

Previous literature on ACs for glyphosate removal is scarce. Among the studies found in 
the literature, the following stand out: the adsorption of glyphosate herbicide using AC derived from newspaper industry residue (Mohsen Nourouzi et al., 2010), the studies of kinetic and equilibrium mechanisms for glyphosate adsorption by biochar obtained from the waste of a bioenergy industry (Mayakaduwa et al., 2015), the study of a steam-activated engineered biochar obtained from rice husks for glyphosate adsorption (Herath et al., 2016), and finally, a study using granular activated carbon (GAC) modified for glyphosate adsorption with graphene oxide and $\mathrm{MnFe}_{2} \mathrm{O}_{4}$ in a fixed-bed column (Marin et al., 2019).

In this study, granular activated carbon from oil palm shell was loaded with manganese and iron $(\mathrm{GAC} / \mathrm{Mn} / \mathrm{Fe})$ to further improve its efficiency, and its performance for glyphosate adsorption in aqueous solution was evaluated. In order to understand the mechanisms that govern the adsorption process, adsorption kinetics and isotherms were obtained and compared to models reported in literature. Thermodynamic parameters were also determined. The developed adsorbent was characterized by several instrumental techniques. All assays were performed to determine its potential on water and wastewater treatment.

\section{MATERIALS AND METHODS}

\subsection{Adsorbent Preparation}

The impregnation method was based on a previous study (Bergamasco, 2010). In summary, $100 \mathrm{~g}$ of GAC 16x52 mesh (Bahiacarbon, Brazil), $40 \mathrm{~mL}$ of deionized water, $30 \mathrm{~mL}$ of ferric chloride solution hexahydrate and $30 \mathrm{~mL}$ of manganese dichloride tetrahydrate solution were added to a round-bottom flask and kept under stirring at $20 \mathrm{rpm}$ and $20^{\circ} \mathrm{C}$ for $24 \mathrm{~h}$ in a rotary evaporator. The solutions of metallic ions were prepared with concentrations in order to achieve a final concentration of $1.0 \% \mathrm{Fe}$ and $0.5 \% \mathrm{Mn}$ on $\mathrm{GAC}(\mathrm{m} / \mathrm{m})$. After this step, the excess water was evaporated under reduced pressure $(-700 \mathrm{mmHg})$ at $60^{\circ} \mathrm{C}$ for $1 \mathrm{~h}$ and the sample was dried overnight at $100^{\circ} \mathrm{C}$. After drying, the sample was transferred to a porcelain crucible and submitted to a thermal treatment at $300^{\circ} \mathrm{C}$ for $3 \mathrm{~h}$. Finally, the sample was washed several times with deionized water to remove non-impregnated particles and metals, followed by drying again in an oven at $100^{\circ} \mathrm{C}$. The final product was named GAG/Mn/Fe.

\subsection{Adsorbent Characterization}

GAC and GAC/Mn/Fe morphology and elemental composition were determined by a Shimadzu SS-550 scanning electron microscope (SEM) coupled with an energy-dispersive Xray spectrometer (EDX). To investigate the textural and surface properties of the adsorbents, nitrogen adsorption-desorption isotherms were obtained at $77 \mathrm{~K}$ using a Quantachrome Autosorb Automated Gas Sorption System (Florida, USA). The specific surface was determined by the Brunauer-Emmett-Teller (BET) method. Pore sizes and volumes were calculated by the Horvath-Kawazoe (HK) and Barrett-Joyner-Hallenda (BJH) methods for micropores and mesopores, respectively. Zeta-potential analyses were performed by electrophoretic laser Doppler anemometry, using a Delsa NanoTM C Beckman Coulter analyzer.

\subsection{Batch Adsorption Experiments}

Preliminary adsorption tests were conducted batchwise in an orbital shaker with temperature control (Jeio Tech Model SI-300R) to explore glyphosate adsorption behavior using GAC and GAC/Mn/Fe.

Samples of adsorbent $(800 \mathrm{mg})$ were added to aliquots $(80 \mathrm{~mL})$ of glyphosate solutions $(20 \mathrm{mg} / \mathrm{L})$. No additional $\mathrm{pH}$ adjustments were performed, since the toxic effects of each acidbase form of glyphosate are unknown. The acidity of glyphosate solutions before the addition of investigated adsorbents was $\mathrm{pH} 3.8$. Those suspensions were shaken at $150 \mathrm{rpm}$ and $25^{\circ} \mathrm{C}$ during $24 \mathrm{~h}$ and were immediately filtered to achieve solid-liquid separation using a 
microsyringe of acetate cellulose $(0.45 \mu \mathrm{m})$. Glyphosate concentrations were determined using a Metrohm 850 Professional IC ion chromatograph, with a Metrosep column A Supp 7 -

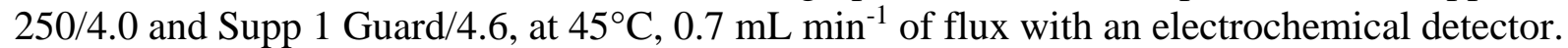

The percentage removal and the amount of glyphosate adsorbed $\left(\mathrm{mg} \mathrm{g}^{-1}\right)$ at equilibrium were analyzed by ion chromatography and calculated as follows Equations 1 and 2:

$$
\begin{aligned}
& \text { Removal (\%) }=\frac{C_{0}-C_{e}}{C_{0}} \times 100 \\
& q_{e}=\frac{\left(C_{0}-C_{e}\right) V}{m}
\end{aligned}
$$

Where $\mathrm{C}_{0}$ and $\mathrm{C}_{\mathrm{e}}$ are the initial glyphosate concentration and the glyphosate concentration at equilibrium $\left(\mathrm{mg} \mathrm{L}^{-1}\right)$, respectively, $\mathrm{q}_{\mathrm{e}}$ is the equilibrium adsorption capacity $\left(\mathrm{mg} \mathrm{g}^{-1}\right), \mathrm{V}$ is the volume of glyphosate solution (L), and $\mathrm{m}$ is the mass of adsorbent $(\mathrm{g})$.

\subsection{Adsorption Kinetics}

Glyphosate adsorption kinetics experiments using GAC/Mn/Fe were performed to determine the equilibrium time and the best kinetic model. Kinetic adsorption experiments were performed using the same previous conditions, shaken for $48 \mathrm{~h}$ at $25^{\circ} \mathrm{C}$ and at the completion of preset time intervals (15, $30 \mathrm{~min}, 1,3,4,5,12,24,36,48 \mathrm{~h})$.

The experimental kinetic data was analyzed using the pseudo-first-order, pseudo-secondorder and the intraparticle model. The linear form of pseudo-first-order kinetic model can be expressed by the following Equation 3:

$$
\ln \left(q_{e}-q_{t}\right)=\ln \left(q_{e}\right)-K_{1} t
$$

Where $\mathrm{q}_{\mathrm{e}}$ and $\mathrm{q}_{\mathrm{t}}$ are the amount of glyphosate adsorbed in $\mathrm{mg} \mathrm{g}^{-1}$ at equilibrium and at time $\mathrm{t}$ (min), respectively, and $\mathrm{K}_{1}$ is the rate constant of adsorption of first-order adsorption $\left(\mathrm{min}^{-1}\right)$. The linearized form of pseudo-second-order model can be represented as follows Equation 4:

$$
\frac{1}{q_{t}}=\frac{1}{K_{2} q_{e}^{2}}+\frac{t}{q_{e}}
$$

Where $\mathrm{K}_{2}\left(\mathrm{~g} \mathrm{mg}^{-1} \mathrm{~min}^{-1}\right)$ is the kinetic rate constant of pseudo-second-order adsorption process. The intraparticle diffusion model is calculated by the Equation 5:

$$
q_{t}=K_{p} t^{0.5}+C
$$

Where $\mathrm{C}$ is a constant related to the diffusion resistance and $\mathrm{K}_{\mathrm{p}}$ is the intraparticle diffusion constant $\left(\mathrm{mg} \mathrm{g}^{-1} \mathrm{~min}^{-0.5}\right)$.

\subsection{Adsorption Isotherms}

The adsorption isotherms experiments were performed also in the same conditions, but varying the temperature $\left(5,15,15,35\right.$ and $\left.45^{\circ} \mathrm{C}\right)$ and the initial concentration of glyphosate $(5$, $10,20,30,40,60$ and $80 \mathrm{mg} / \mathrm{L})$. The stirring was continued until reaching the equilibrium time $(24 \mathrm{~h})$ before samples of the solutions were withdrawn with the microsyringe, and glyphosate concentration was determined immediately. Chromeleon software was used for ion chromatography data processing. OriginPro (Ver. 8.0, OriginLab Co., USA) software was used to define the parameters of kinetic and isotherm models with statistical evaluation data by nonlinear regressions.

The adsorption data obtained from the adsorption equilibrium isotherms were analyzed with respect to the Langmuir and Freundlich isotherm equations (Freundlich, 1907; Langmuir, 1918). The Langmuir model, assuming a monolayer adsorption on a surface having a finite 
number of identical sites for adsorption with uniform adsorption energies is represented as Equation 6:

$q_{e}=\frac{K_{L} q_{m} C_{e}}{1+K_{a d} C_{e}}$

Where $\mathrm{q}_{\mathrm{e}}$ is the amount of glyphosate adsorbed at the equilibrium ( $\left.\mathrm{mg} \mathrm{g}^{-1}\right), \mathrm{q}_{\mathrm{m}}$ is the maximum adsorption capacity at monolayer coverage $\left(\mathrm{mg} \mathrm{g}^{-1}\right)$, and $\mathrm{K}_{\mathrm{L}}\left(\mathrm{mg} \mathrm{g}^{-1}\right)$ is the Langmuir adsorption equilibrium constant.

The Freundlich isotherm considers non-ideal sorption on heterogeneous surfaces and a multilayer sorption. It can be described by the following Equation 7:

$$
q_{e}=K_{F} C_{e}^{l / n}
$$

Where $\mathrm{K}_{\mathrm{F}}\left(\left(\mathrm{L} \mathrm{mg}^{-1}\right)\left(\mathrm{L} \mathrm{mg}^{-1}\right)^{1 / \mathrm{n}}\right)$ and $\mathrm{n}$ are Freundlich constants.

\subsection{Thermodynamics Parameters}

The thermodynamic parameters of adsorption were determined to provide information of energetic changes and define the spontaneity of the process.

Assuming that the activity coefficient does not change at low temperature, the Gibb's free energy $\left(\Delta \mathrm{G}^{\circ}\right)$, enthalpy $\left(\Delta \mathrm{H}^{\circ}\right)$ and entropy $\left(\Delta \mathrm{S}^{\circ}\right)$ changes were calculated by the following Equations 8 and 9:

$\Delta G^{\circ}=-R T \ln K_{C}$

$\ln K_{C}=\frac{\Delta S^{\circ}}{R}-\frac{\Delta H^{\circ}}{R T}$

Where $\mathrm{T}$ is the absolute temperature $(\mathrm{K})$ and $\mathrm{R}$ is the universal gas constant $\left(8.314 \mathrm{~J} \mathrm{~mol}^{-1} \mathrm{~K}^{-1}\right)$. The thermodynamic equilibrium constant $\left(\mathrm{K}_{\mathrm{C}}\right)$ is defined by Equation 10:

$$
K_{C}=\frac{q_{e}}{C_{e}}
$$

$\mathrm{K}_{\mathrm{C}}$ was calculated by the equilibrium constant method by plotting $\ln \left(\mathrm{q}_{\mathrm{e}} / \mathrm{C}_{\mathrm{e}}\right)$ versus $\mathrm{q}_{\mathrm{e}}$ (SALVESTRINI et al., 2014).

\section{RESULTS AND DISCUSSION}

\subsection{Adsorbent characterization}

The SEM patterns of the GAC and GAC/Mn/Fe in this study had the same characteristics of plain GAC, and no other crystalline phases were observed. The usual rough surface texture of GAC can be seen in Figure 1, showing a porous surface and a distribution of pores of an irregular size and shape in both samples.

Comparing both SEM images, an increase in material deposition on the GAC surface after impregnation was observed; possibly indicating a metal compound deposition. Which was confirmed by EDX analysis.

In the corresponding EDX spectrum, Table 1, the elemental composition of GAC can be observed with the presence of carbon, oxygen, and some elements such as aluminum, silica and chlorine, were also identified in studies reported by other authors (Giri et al., 2012; Haro et al., 2012; Mohan et al., 2011; Qu et al., 2009). In the EDX spectra of GAC/Mn/Fe, the presence of $\mathrm{Mn}$ and $\mathrm{Fe}$ was also observed, in addition to signs referring to the elements commonly present 
in GAC samples of vegetable origin (Arakawa et al., 2019b).

EDX analysis revealed that GAG did not contain any $\mathrm{Fe}$ and $\mathrm{Mn}$, while $\mathrm{GAC} / \mathrm{Mn} / \mathrm{Fe}$ presented $0.24 \%$ of $\mathrm{Mn}$ and $1.1 \%$ of $\mathrm{Fe}$, indicating that the humid impregnation process may be a reliable technique for coating the surface of GAC with Fe and Mn. It is worth remembering that the EDX technique is a qualitative technique and not a reliable quantitative technique.
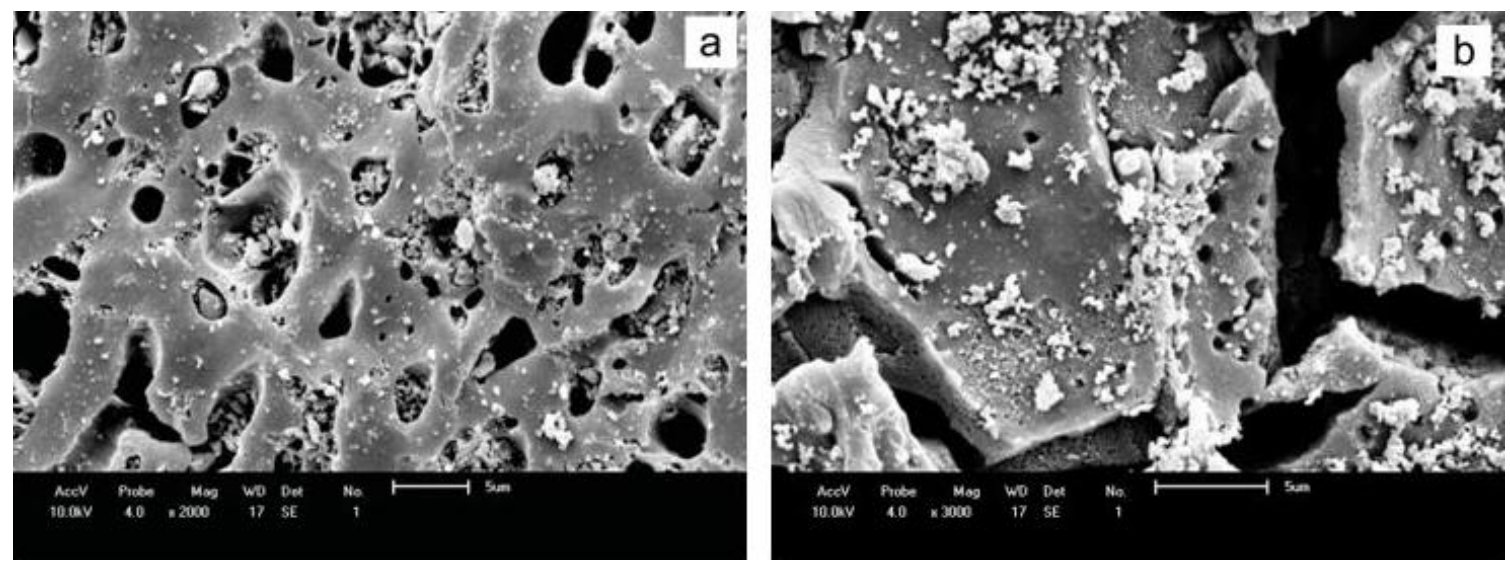

Figure 1. SEM images of GAC (a) and GAC/Mn/Fe (b) surfaces at 2000x magnification.

Table 1. SEM-EDX analysis results for GAC and GAC/Mn/Fe.

\begin{tabular}{ccccccccc}
\hline \multicolumn{2}{c}{ Element } & $\mathbf{C}$ & $\mathbf{O}$ & $\mathrm{Al}$ & $\mathrm{Si}$ & $\mathbf{C l}$ & $\mathbf{M n}$ & $\mathbf{F e}$ \\
\hline \multirow{2}{*}{ At $(\%)$} & $\mathrm{GAC}$ & 78.59 & 15.89 & 0.81 & 3.10 & 1.62 & - & - \\
& $\mathrm{GAC} / \mathrm{Mn} / \mathrm{Fe}$ & 81.21 & 15.33 & 0.14 & 0.13 & 1.86 & 0.24 & 1.10 \\
\hline
\end{tabular}

The results of textural properties and zeta potential analysis of GAC and GAC/Mn/Fe are presented in Figure 2.
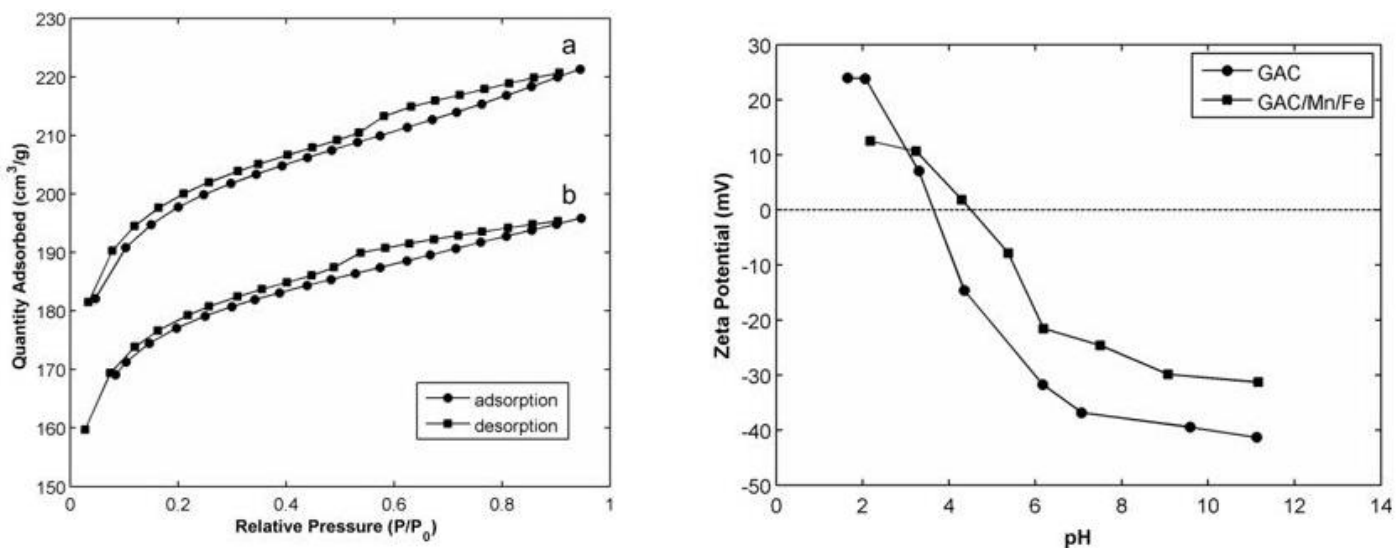

Figure 2. $\mathrm{N}_{2}$ adsorption-desorption isotherms at $77 \mathrm{~K}$ of $\mathrm{GAC}$ (a) and $\mathrm{GAC} / \mathrm{Mn} / \mathrm{Fe}$ (b) and $\mathrm{pH}$ dependent zeta-potential plots of GAG and GAG/Mn/Fe (c).

According to Figure 2c, it was determined that the isoelectric point (IEP) of GAC is at $\mathrm{pH}=3.7$. This indicates that when the $\mathrm{pH}$ of solution is less than the IEP, the surface of the adsorbent is positively charged, which is beneficial for adsorbing anions, and when the $\mathrm{pH}$ of the solution is higher than the IEP, cation adsorption is favored due to the negatively charged material's surface (Marin et al., 2019). After the metal impregnation it was observed that the IEP shifted to a higher value; thus for GAC/Mn/Fe, the IEP was approximately at $\mathrm{pH}=4.5$. Possibly this occurred due to the addition of manganese and iron ions, which are positively 
charged, during the humid impregnation.

Glyphosate belongs to the phosphonated amino acids group and has the capacity of presenting both positive and negative charges, due to its amphoteric characteristics. Although glyphosate mainly exhibits a negative charge, it can be uncharged or have a positive charge at a pH below 2.29, and the number of negative charges increases with the $\mathrm{pH}$ (Yamaguchi et al., 2016). Thus, the loading of $\mathrm{Mn}$ and Fe ions may have the potential of increased capacity for glyphosate adsorption when compared to plain GAC, possibly due to electrostatic attraction, since glyphosate charge is negative in the working conditions (Yamaguchi et al., 2016).

According to the International Union of Pure and Applied Chemistry (IUPAC) classification, Figure 2 presents a physisorption isotherm type I(b) for both adsorbents. This kind of isotherm is given by microporous materials, with an enhanced adsorbent-adsorptive interactions with wider micropores $(<2.5 \mathrm{~nm})$ leading to a steep uptake at a very low $\mathrm{p} / \mathrm{p}_{0}$. The type $\mathrm{H} 4$ hysteresis loop of microporous materials was also observed in both adsorbents. It also may indicate the presence of slit-shaped pores with narrow sizes (Thommes et al., 2015).

The calculated surface characteristics parameters using BET, BJH and HK methods are presented in Table 2 .

Table 2. Surface characteristics parameters calculated using BET, BJH and HK equations.

\begin{tabular}{lllllll}
\hline \multirow{2}{*}{ Sample } & \multirow{2}{*}{$\mathbf{S}_{\text {BET }}\left(\mathbf{m}^{2 /} \mathbf{g}\right)$} & \multirow{2}{*}{$\mathbf{S}_{\text {micro }}\left(\mathbf{m}^{2 /} \mathbf{g}\right)$} & \multicolumn{2}{l}{$\mathbf{V}\left(\mathbf{c m}^{3} / \mathbf{g}\right)$} & \multicolumn{2}{c}{$\mathbf{D}(\mathbf{n m})$} \\
\cline { 5 - 7 } & & & HK & BJH & HK & BJH \\
\hline GAC & 610 & 547 & 0.3 & 0.04 & 1.6 & 4.6 \\
GAC/Mn/Fe & 532 & 484 & 0.3 & 0.04 & 1.6 & 4.2 \\
\hline
\end{tabular}

The impregnation of activated carbon with metal compounds lead to the lowering of the BET surface from $610 \mathrm{~m}^{2} / \mathrm{g}$ of plain GAC to $532 \mathrm{~m}^{2} / \mathrm{g}$ for GAC/Mn/Fe. This phenomenon is probably caused by two factors: pore-blocking being a result of metals and carbon matrix interaction and the generation of a large number of the surface oxygen complexes. Other authors had reported such behavior previously in similar studies (Gaur et al., 2007; Goscianska et al., 2012; Mondal et al., 2009). Micropore surface area was also decreased, confirming the metalloading on micropores. It is important to remark that this blockage did not affect the volume and diameter of micropores.

It was observed that the volume of mesopores calculated by the $\mathrm{BJH}$ method did not change, but the average diameter decreased, indicating that metals were also loaded in mesopores, and not only in micropores. Comparing the proportion of micropore area and BET area $\left(\mathrm{S}_{\text {micro }} / \mathrm{S}_{\mathrm{BET}}\right)$, before impregnation the proportion was nearly $89.67 \%$ and after impregnation it increased to $90.97 \%$. These results may indicate that the deposition of metal compounds in mesopores may lead to the decrease in the mesopore volume, converting them into micropores. These results may suggest that the impregnation treatment lead to metal compounds, especially in mesopores (Arakawa et al., 2019a).

\subsection{Adsorption studies}

To study the adsorption of glyphosate onto GAC/Mn/Fe, preliminary batch adsorption experiments were conducted as explained in the previous section. The results are shown in Figure 3.

It was observed that GAC presented a very low capacity for glyphosate removal (22\%), while GAC/Mn/Fe presented a very high glyphosate removal (96\%). This can be justified by the IEP, that was found to be 4.5 and 3.7 for GAC/Mn/Fe and GAC, respectively. GAC presents a negative charge at $\mathrm{pH} 3.8$ and glyphosate charge is also negative at this $\mathrm{pH}$ condition, being unfavorable to glyphosate removal. In contrast, $\mathrm{GAC} / \mathrm{Mn} / \mathrm{Fe}$ is positive at $\mathrm{pH} 3.8$, and it is favorable to adsorb anions via electrostatic attraction under these $\mathrm{pH}$ conditions. 


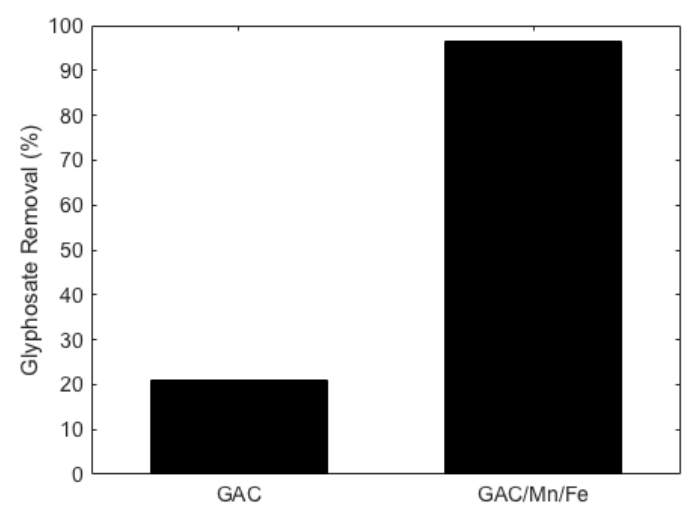

Figure 3. Adsorption percentage of GAC and $\mathrm{GAC} / \mathrm{Mn} / \mathrm{Fe} \quad(80 \mathrm{~mL}$ glyphosate solution $(20 \mathrm{mg} / \mathrm{L}), 800 \mathrm{mg}$ adsorbent, at $25^{\circ} \mathrm{C}, 150 \mathrm{rpm}, 24 \mathrm{~h}$ and $\left.\mathrm{pH}=3.8\right)$.

\subsection{Adsorption Kinetics}

The kinetics studies of adsorption are essential in designing appropriate adsorption technologies because they describe the solute adsorption rate. Thus, the adsorption of glyphosate onto $\mathrm{GAC} / \mathrm{Mn} / \mathrm{Fe}$ was studied at different time intervals and the graphical representation is shown in Figure 4.

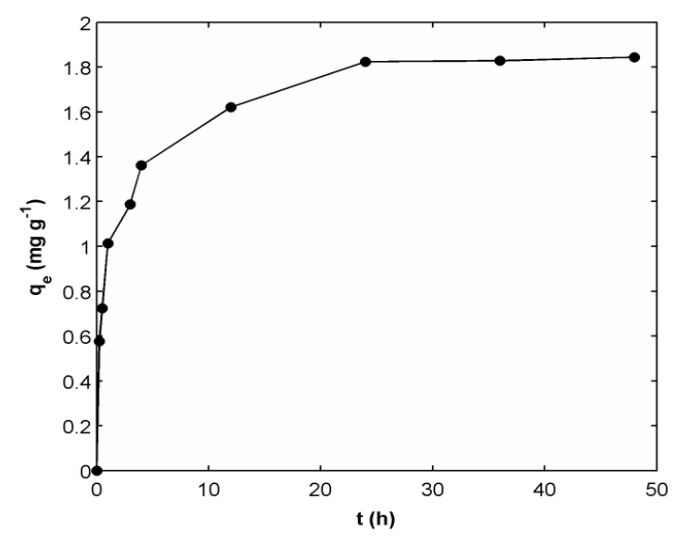

Figure 4. Glyphosate adsorption kinetics by $\mathrm{GAC} / \mathrm{Mn} / \mathrm{Fe} \quad(80 \mathrm{~mL}$ glyphosate solution $(20 \mathrm{mg} / \mathrm{L}), 800 \mathrm{mg}$ adsorbent, at $25^{\circ} \mathrm{C}, 150 \mathrm{rpm}, \mathrm{pH}=3.8$, and $\mathrm{t}=0-48 \mathrm{~h}$ ).

The adsorption rate was fast at the beginning of the process, and then it slowed down until it reached the equilibrium at about $24 \mathrm{~h}$. The long time required to reach the equilibrium can be attributed to the microporous structure of GAC, that would inevitably result in a slower solute uptake rate than macroporous and mesoporous materials (Cui et al., 2012).

It is possible to observe a relatively rapid phase of glyphosate adsorption within the first 4 $\mathrm{h}$ of contact time, which resulted in $1.36 \mathrm{mg} \mathrm{g}^{-1}$ (73.8\%) of glyphosate adsorption, followed by a slow adsorption that reached the equilibrium after $24 \mathrm{~h}$ with glyphosate adsorption of $1.82 \mathrm{mg}$ $\mathrm{g}^{-1}(98.9 \%)$. The two-phase adsorption is a phenomenon which occurs through a rapid phase and a slow phase. This can be explained by the active sites available on GAC/Mn/Fe that become progressively saturated with time, and therefore it results in a slow adsorption. The initial rapid adsorption at contact time is due to the wide availability of active sites positively charged on $\mathrm{GAC} / \mathrm{Mn} / \mathrm{Fe}$ for glyphosate interaction and the decrease in adsorption over time is probably due to electrostatic hindrance between the surface of $\mathrm{GAC} / \mathrm{Mn} / \mathrm{Fe}$ and the negatively charged glyphosate (Herath et al., 2016). 
The adsorption kinetics data were fitted in linear kinetics models as Equations 3-5. The values estimated of the kinetic model parameters and the coefficient of determination $\left(\mathrm{R}^{2}\right)$ are given in Table 3 .

Table 3. Adsorption kinetics models parameters.

\begin{tabular}{lccccccccc}
\hline Experimental & \multicolumn{3}{c}{ Pseudo-first-order } & \multicolumn{2}{c}{ Pseudo-second-order } & \multicolumn{3}{c}{ Intraparticle diffusion } \\
\hline $\mathrm{qe}_{\mathrm{e}}\left(\mathrm{mg} \mathrm{g}^{-1}\right)$ & $\mathrm{K}_{1}\left(\mathrm{~min}^{-1}\right)$ & $\begin{array}{c}\mathrm{q}_{\mathrm{e}, \mathrm{cal}} \\
\left(\mathrm{mg} \mathrm{g}^{-1}\right)\end{array}$ & $\mathrm{R}^{2}$ & $\begin{array}{c}\mathrm{K}_{2} \\
\left(\mathrm{~g} \mathrm{mg}^{-1} \mathrm{~min}^{-1}\right)\end{array}$ & $\begin{array}{c}\mathrm{q}_{\mathrm{e}, \mathrm{cal}} \\
\left(\mathrm{mg} \mathrm{g}^{-1}\right)\end{array}$ & $\mathrm{R}^{2}$ & $\begin{array}{c}\mathrm{K}_{\mathrm{p}} \\
\left(\mathrm{mg} \mathrm{g}^{-1} \mathrm{~min}^{-0.5}\right)\end{array}$ & $\mathrm{C}$ & $\mathrm{R}^{2}$ \\
\hline 1.844 & 0.002 & 1.100 & 0.944 & 0.009 & 1.877 & 0.999 & 0.062 & 0.401 & 0.942 \\
\hline
\end{tabular}

The pseudo-second order model is assumed to involve chemisorption with valence forces through sharing or exchange electrons between the adsorbent and the adsorbate as the ratecontrolling step (Mayakaduwa et al., 2015). The result of the glyphosate adsorption kinetic was better described by the pseudo-second order model than the other kinetic models applied in this study. Calculated $\mathrm{R}^{2}$ values from linear regression (Table 3 ) indicate that the best fit was obtained with the pseudo-second order model. The best-fitting of the experimental data to the pseudo-second order model is also proven by the adsorption capacity value $\left(1.877 \mathrm{mg} \mathrm{g}^{-1}\right)$ that is very close to the experimental value $\left(1.844 \mathrm{mg} \mathrm{g}^{-1}\right)$. This bearing suggests that the adsorption of glyphosate onto $\mathrm{GAC} / \mathrm{Mn} / \mathrm{Fe}$ would be more inclined towards chemisorption mechanism.

Moreover, the coefficients associated with the intraparticle diffusion model were calculated. Two linear stages were observed in the results, and the coefficient for each stage are presented in Table 3. The initial stage shows the boundary layer diffusion and the second linear stage shows the intraparticle diffusion effect. The linear portions of the plots do not pass through the origin. This indicates that the adsorption mechanism of glyphosate onto GAC/Mn/Fe is complex and both surface adsorption as well as intraparticle diffusion contributes to the ratedetermining step (Thamilarasu et al., 2013).

\subsection{Adsorption isotherms}

The effect of temperature on glyphosate adsorption and the prediction of maximum adsorption capacities of the adsorbent are conducted by the analysis of the adsorption isotherms data. Figure 5 presents the adsorption isotherms of glyphosate onto GAC/Mn/Fe for five different temperatures.

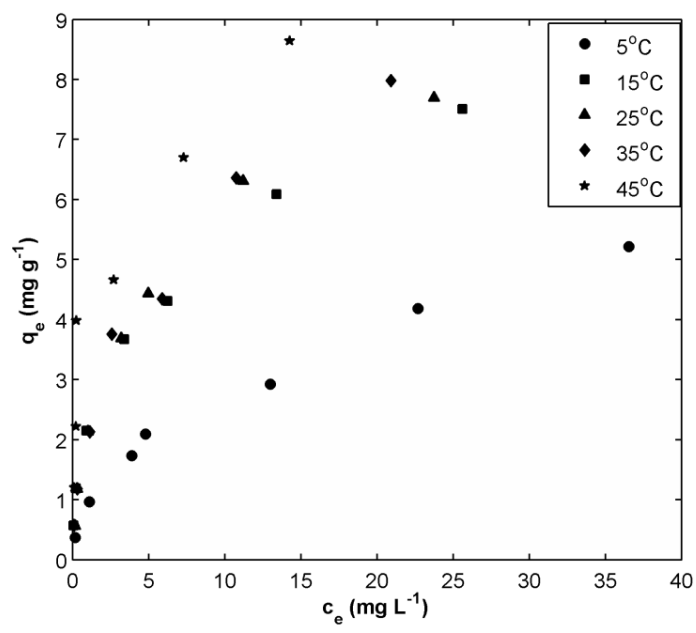

Figure 5. Glyphosate adsorption isotherms on $\mathrm{GAC} / \mathrm{Mn} / \mathrm{Fe}(80 \mathrm{~mL}$ glyphosate solution, glyphosate initial concentration $=5-80$ $\mathrm{mg} / \mathrm{L}), 800 \mathrm{mg}$ adsorbent, at $25^{\circ} \mathrm{C}, 150 \mathrm{rpm}$, $\mathrm{pH}=3.8$, and $\mathrm{t}=24 \mathrm{~h}$ ).

\section{IPABHî}


The increase in temperature decreases glyphosate adsorption, clearly revealing the endothermic character of the adsorption process. The maximum adsorption capacity obtained was $9.19 \mathrm{mg} \mathrm{g}^{-1}$ at $45^{\circ} \mathrm{C}$, the highest temperature investigated. The data was fitted for Langmuir and Freundlich isotherm models for all temperatures studied and isotherm parameters calculated are listed in Table 4.

Table 4. Langmuir and Freundlich model parameters.

\begin{tabular}{ccccccc}
\hline $\mathbf{T}\left({ }^{\circ} \mathbf{C}\right)$ & \multicolumn{3}{c}{ Langmuir model } & \multicolumn{3}{c}{ Freundlich model } \\
\hline & $\mathrm{q}_{\mathrm{m}}\left(\mathrm{mg} \mathrm{g}^{-1}\right)$ & $\mathrm{K}_{\mathrm{L}}\left(\mathrm{L} \mathrm{mg}^{-1}\right)$ & $\mathrm{R}^{2}$ & $\mathrm{~K}_{\mathrm{F}}\left(\mathrm{L} \mathrm{mg}^{-1}\right)$ & $1 / \mathrm{n}$ & $\mathrm{R}^{2}$ \\
\hline 5 & 6.523 & 0.085 & 0.958 & 0.903 & 0.486 & 0.995 \\
15 & 8.441 & 0.217 & 0.920 & 2.080 & 0.411 & 0.996 \\
25 & 8.793 & 0.239 & 0.980 & 2.137 & 0.411 & 0.984 \\
35 & 9.003 & 0.278 & 0.984 & 2.372 & 0.404 & 0.982 \\
45 & 9.178 & 0.490 & 0.926 & 3.030 & 0.398 & 0.981 \\
\hline
\end{tabular}

It can be seen that the agreement between experimental data and both predicted isotherm models for glyphosate adsorption was obtained. The Freundlich model showed higher coefficients of determination $\left(\mathrm{R}^{2}>0.98\right)$ than the Langmuir model, indicating that the Freundlich model is more appropriate to express the adsorption isotherm of $\mathrm{GAC} / \mathrm{Mn} / \mathrm{Fe}$ adsorbing glyphosate from aqueous solution. This result may be due to the heterogeneous distribution of active sites on GAC/Mn/Fe surface, suggesting that glyphosate adsorption on $\mathrm{GAC} / \mathrm{Mn} / \mathrm{Fe}$ is of a multilayer physical type with different adsorption energies (Herath et al., 2016). The obtained result can be confirmed with the morphology characterization, which showed an evidently heterogeneous surface, with different compounds on the surface (Figure 1).

The adsorption intensity can be related to the Freundlich constant $(1 / \mathrm{n})$, when $0.1<1 / \mathrm{n} \leq 1$, it is considered easy to adsorb and when $1 / \mathrm{n}>1$ it is considered difficult to adsorb (Liu et al., 2012). According to the Freundlich constant, the results indicated that glyphosate was easily adsorbed onto GAC/Mn/Fe.

Comparing some maximum adsorption capacities from different adsorbent materials found in previous literature (activated carbon derived from waste newspaper $\left(\mathrm{q}_{\mathrm{m}}=48 \mathrm{mg} / \mathrm{g}\right.$ ) (Mohsen Nourouzi et al., 2010), biochar obtained as a waste byproduct from a bioenergy industry $\left(\mathrm{q}_{\mathrm{m}}=44\right.$ $\mathrm{mg} / \mathrm{g}$ ) (Mayakaduwa et al., 2015), biochar derived from rice husk ( $\mathrm{q}_{\mathrm{m}}=123 \mathrm{mg} / \mathrm{g}$ ) (Herath et $a l ., 2016))$ the present study $\mathrm{CAG} / \mathrm{Mn} / \mathrm{Fe}$ obtained the lowest glyphosate removal $\left(\mathrm{q}_{\mathrm{m}}=9.19\right.$ $\mathrm{mg} / \mathrm{g}$ ). This might have happened due to all-cited literature having used powder-activated carbon with particle size $<1 \mathrm{~mm}$ instead of the GAC that was used in the present study $(0.425$ to $1.18 \mathrm{~mm}$ ), leading to a smaller specific surface, and thus, a reduced adsorption potential. A higher specific surface may be very advantageous, but the small size of the adsorbent particles may lead to hydraulic problems, such as plugging, high hydraulic retention times, pressure drops, disposal and handling concerns and losses (Dwivedi et al., 2008).

However, the maximum adsorption capacity of $\mathrm{CAG} / \mathrm{Mn} / \mathrm{Fe}$ obtained in this study was superior to the result obtained in a previous study using activated carbon functionalized with $\mathrm{MnFe}_{2} \mathrm{O}_{4}$ and graphene oxide in a fixed-bed column for glyphosate adsorption $\left(\mathrm{q}_{\mathrm{m}}=3.7-5.5\right.$ $\mathrm{mg} / \mathrm{g}$ ), which also used a granular activated carbon, despite the fact that it is known that fixedbed columns present different adsorption results from batch experiments (Marin et al., 2019).

\subsection{Thermodynamic parameters}

Thermodynamic parameters calculated are reported in Table 5. 
Table 5. Thermodynamic parameters.

\begin{tabular}{cccc}
\hline Temperature $(\mathbf{K})$ & $\boldsymbol{\Delta} \mathbf{G}^{\circ}\left(\mathbf{k J ~ m o l}^{\mathbf{1}}\right)$ & $\mathbf{\Delta} \mathbf{H}^{\circ}\left(\mathbf{k J ~ m o l}^{-1}\right)$ & $\Delta \mathbf{S}^{\circ}\left(\mathbf{J ~ m o l}^{-\mathbf{1}} \mathbf{K}^{-\mathbf{1}}\right)$ \\
\hline 5 & 0.527 & & \\
15 & -0.281 & & \\
25 & -0.970 & 20.924 & -73.250 \\
35 & -1.275 & & \\
45 & -2.606 & & \\
\hline
\end{tabular}

The values of $\Delta \mathrm{S}^{\circ}$ are negative, which implies that glyphosate molecules lost randomness in the solid-liquid interface during the adsorption process (Maneerung et al., 2016). Moreover, $\Delta \mathrm{S}^{\circ}$ value is considerable, which may suggest that the orderliness during the adsorption process is really altered. Alterations in orderliness could be related to a dehydration process, which could have generated a pseudo-ion-exchange (Silva-Medeiros et al., 2016).

$\Delta \mathrm{G}^{\circ}$ values are also negative, except for the temperature of $5^{\circ} \mathrm{C}$, indicating that the glyphosate adsorption by $\mathrm{GAC} / \mathrm{Mn} / \mathrm{Fe}$ is a spontaneous process. By increasing temperature, $\Delta \mathrm{G}^{\circ}$ values become more negative, suggesting that glyphosate adsorption becomes more thermodynamically favored and feasible (Zhou et al., 2014).

From Table 5, it was revealed that the adsorption of glyphosate onto GAC/Mn/Fe was an endothermic process due to the positive value of $\Delta \mathrm{H}^{\circ}$, which is sustained by increased glyphosate adsorption with increasing temperature (Fan et al., 2012). Moreover, the calculated value for change in enthalpy is $20.924 \mathrm{~kJ} \mathrm{~mol}^{-1}$. When the $\Delta \mathrm{H}^{\circ}$ range is between $5-10 \mathrm{~kJ} \mathrm{~mol}^{-1}$, the adsorption mechanism is physiosorption, and when the $\Delta \mathrm{H}^{\circ}$ is between $30-40 \mathrm{~kJ} \mathrm{~mol}^{-1}$, the adsorption belongs to chemisorption. In this work, the $\Delta \mathrm{H}^{\circ}$ value suggests that the adsorption process is neither fully physical nor fully chemical and some complex mechanism dictated the adsorption process (Chen et al., 2012; Li et al., 2011).

\section{CONCLUSIONS}

Activated carbon impregnated with manganese and iron was successfully synthesized via the humid-impregnation technique. The characterization studies indicated a decrease in the calculated BET surface to $532 \mathrm{~m}^{2} / \mathrm{g}$ due to partial pore blockage; however, its microporous characteristics prevailed, which was confirmed by the isotherm type $1 \mathrm{~b}$ and hysteresis loop type $\mathrm{H} 4$. The modification has also increased the IEP of GAC/Mn/Fe to $\mathrm{pH}=4.5$, leading to a morepositive charge. The results of adsorption showed that the adsorption capacity of $\mathrm{CAG} / \mathrm{Mn} / \mathrm{Fe}$ was improved with a higher adsorption rate for glyphosate when compared to plain GAC. The maximum adsorption capacity of GAC/Mn/Fe for glyphosate was $9.19 \mathrm{mg} \mathrm{g}^{-1}$ at $45^{\circ} \mathrm{C}$. Batch kinetic data fitted well $\left(\mathrm{R}^{2}>0.99\right)$ with pseudo-second-order kinetics while isotherm data were well described $\left(\mathrm{R}^{2}>0.98\right)$ by the Freundlich isotherm model. The glyphosate adsorption process onto GAC/Mn/Fe was shown to be spontaneous $\left(\Delta \mathrm{G}^{\circ}<0\right)$ and endothermic, with a $\Delta \mathrm{H}^{\circ}$ of $20.924 \mathrm{~kJ} \mathrm{~mol}^{-1}$ and $\Delta \mathrm{S}^{\circ}-73.250 \mathrm{~J} \mathrm{~mol}^{-1} \mathrm{~K}^{-1}$. This study demonstrated that the synthesized $\mathrm{GAC} / \mathrm{Mn} / \mathrm{Fe}$ is a promising adsorbent for glyphosate removal from aqueous solution for water treatment.

\section{ACKNOWLEDGEMENTS}

The authors would like to thank the Coordenação de Aperfeiçoamento de Pessoal de Nível Superior (CAPES - Brazil), the Conselho Nacional de Desenvolvimento Científico e Tecnológico (CNPq - Brazil), the Instituto Cesumar de Ciência, Tecnologia e Inovação (ICETI - Brazil) for supporting this project. 


\section{REFERENCES}

ARAKAWA, F. S.; SHIMABUKU-BIADOLA, Q. L.; FERNANDES SILVA, M.; BERGAMASCO, R. Development of a new vacuum impregnation method at room atmosphere to produce silver-copper oxide nanoparticles on activated carbon for $\begin{array}{llll}\text { antibacterial applications. } & \text { Environmental Technology, }\end{array}$ https://doi.org/10.1080/09593330.2019.1567607

ARAKAWA, F. S.; SHIMABUKU-BIADOLA, Q. L.; DE LIMA BAZANA, S.; SILVA, M. F.; DE ABREU FILHO, B. A.; BERGAMASCO, R. Activated carbon impregnation with ag and cu composed nanoparticles for escherichia coli contaminated water treatment. The Canadian Journal of Chemical Engineering, v. 97, n. 9, p. 2408-2418, 2019b. https://doi.org/10.1002/cjce.23471

BATTAGLIN, W. A.; KOLPIN, D. W.; SCRIBNER, E. A.; KUIVILA, K. M.; SANDSTROM, M. W. Glyphosate, other herbicides, and transformation products in midwestern streams. JAWRA Journal of the American Water Resources Association, v. 41, n. 2, p. 323 332, 2005. https://doi.org/10.1111/j.1752-1688.2005.tb03738.x

BERGAMASCO, R. Carvão ativado impregnado com prata e cobre para eliminação de microrganismos da água. Brasil n. PI 016.100.000.478, 2010.

BHATNAGAR, A.; HOGLAND, W.; MARQUES, M.; SILLANPÄ̈̈, M. An overview of the modification methods of activated carbon for its water treatment applications. Chemical $\begin{array}{lllllll}\text { Engineering Journal, } & \text { v. 219, } & \text { n. } & 013 .\end{array}$ https://doi.org/10.1016/j.cej.2012.12.038

CHEN, F.-X.; ZHOU, C.-R.; LI, G.-P.; PENG, F.-F. Thermodynamics and kinetics of glyphosate adsorption on resin D301. Arabian Journal of Chemistry, v. 9, n. 2, p. S1665-S1669, 2012. https://doi.org/10.1016/j.arabjc.2012.04.014

CUI, H.; LI, Q.; QIAN, Y.; ZHANG, Q.; ZHAI, J. Preparation and adsorption performance of MnO2/PAC composite towards aqueous glyphosate. Environmental Technology, v. 33, n. 16-18, p. 2049-2056, 2012. https://doi.org/10.1080/09593330.2012.660641

DWIVEDI, C. P.; SAHU, J. N.; MOHANTY, C. R.; MOHAN, B. R.; MEIKAP, B. C. Column performance of granular activated carbon packed bed for $\mathrm{Pb}$ (II) removal. Journal of Hazardous Materials, v. 156, n. 1, p. 596-603, 2008.

FAN, L.; LUO, C.; LI, X.; LU, F.; QIU, H.; SUN, M. Fabrication of novel magnetic chitosan grafted with graphene oxide to enhance adsorption properties for methyl blue. Journal $\begin{array}{lllll}\text { of Hazardous Materials, v. 215-216, p. 272-279, } 2012 . & \text { v. }\end{array}$ https://doi.org/10.1016/j.jhazmat.2012.02.068

FREUNDLICH, H. Über die Adsorption in Lösungen. Zeitschrift für Physikalische Chemie, v. 57U, n. 1, p. 385-470, 1907. https://doi.org/10.1515/zpch-1907-5723

GAUR, V.; SHARMA, A.; VERMA, N. Removal of SO2 by Activated Carbon Fibre Impregnated with Transition Metals. The Canadian Journal of Chemical Engineering, v. 85 , n. 2, p. 188-198, 2007. https://doi.org/10.1002/cjce.5450850207

GHAEDI, M.; ANSARI, A.; HABIBI, M. H.; ASGHARI, A. R. Removal of malachite green from aqueous solution by zinc oxide nanoparticle loaded on activated carbon: Kinetics and isotherm study. Journal of Industrial and Engineering Chemistry, v. 20, n. 1, p. 17-28, 2014. https://doi.org/10.1016/j.jiec.2013.04.031 
GIRI, A. K.; PATEL, R.; MANDAL, S. Removal of Cr (VI) from aqueous solution by Eichhornia crassipes root biomass-derived activated carbon. Chemical Engineering Journal, v. 185-186, p. 71-81, 2012. https://doi.org/10.1016/j.cej.2012.01.025

GOSCIANSKA, J.; NOWAK, I.; NOWICKI, P.; PIETRZAK, R. The influence of silver on the physicochemical and catalytic properties of activated carbons. Chemical Engineering Journal, v. 189-190, p. 422-430, 2012. https://doi.org/10.1016/j.cej.2012.02.069

GUPTA, V. K.; SALEH, T. A. Sorption of pollutants by porous carbon, carbon nanotubes and fullerene- An overview. Environmental Science and Pollution Research, v. 20, n. 5, p. 2828-2843, 2013. https://doi.org/10.1007/s11356-013-1524-1

HAGNER, M.; PENTTINEN, O.-P.; TIILIKKALA, K.; SETÄLÄ, H. The effects of biochar, wood vinegar and plants on glyphosate leaching and degradation. European Journal of Soil Biology, v. 58, n., p. 1-7, 2013. https://doi.org/10.1016/j.ejsobi.2013.05.002

HARO, M.; RUIZ, B.; ANDRADE, M.; MESTRE, A. S.; PARRA, J. B.; CARVALHO, A. P.; ANIA, C. O. Dual role of copper on the reactivity of activated carbons from coal and lignocellulosic precursors. Microporous and Mesoporous Materials, v. 154, n. 0, p. 6873, 2012. https://doi.org/10.1016/j.micromeso.2011.07.005

HERATH, I.; KUMARATHILAKA, P.; AL-WABEL, M. I.; ABDULJABBAR, A.; AHMAD, M.; USMAN, A. R. A.; VITHANAGE, M. Mechanistic modeling of glyphosate interaction with rice husk derived engineered biochar. Microporous and Mesoporous Materials, v. 225, n., p. 280-288, 2016. https://doi.org/10.1016/j.micromeso.2016.01.017

HU, Y. S.; ZHAO, Y. Q.; SOROHAN, B. Removal of glyphosate from aqueous environment by adsorption using water industrial residual. Desalination, v. 271, n. 1-3, p. 150-156, 2011. https://doi.org/10.1016/j.desal.2010.12.014

LANGMUIR, I. The adsorption of gases on plane surfaces of glass, mica and platinum. Journal of American Chemical Society, v. 40, n. 9, p. 1361-0403, 1918. https://doi.org/10.1021/ja02242a004

LI, X.; ZHOU, X.; MU, J.; LU, L.; HAN, D.; LU, C.; WANG, M. Thermodynamics and Kinetics of p-Aminophenol Adsorption on Poly(aryl ether ketone) Containing Pendant Carboxyl Groups. Journal of Chemical \& Engineering Data, v. 56, n. 11, p. 4274-4277, 2011. https://doi.org/10.1021/je2009297

LIU, T.; LI, Y.; DU, Q.; SUN, J.; JIAO, Y.; YANG, G.; WANG, Z.; XIA, Y.; ZHANG, W.; WANG, K.; ZHU, H.; WU, D. Adsorption of methylene blue from aqueous solution by graphene. Colloids and Surfaces B: Biointerfaces, v. 90, p. 197-203, 2012. https://doi.org/10.1016/j.colsurfb.2011.10.019

MANEERUNG, T.; LIEW, J.; DAI, Y.; KAWI, S.; CHONG, C.; WANG, C.-H. Activated carbon derived from carbon residue from biomass gasification and its application for dye adsorption: Kinetics, isotherms and thermodynamic studies. Bioresource Technology, v. 200, n., p. 350-359, 2016. https://doi.org/10.1016/j.biortech.2015.10.047

MARIN, P.; BERGAMASCO, R.; MÓDENES, A. N.; PARAISO, P. R.; HAMOUDI, S. Synthesis and characterization of graphene oxide functionalized with $\mathrm{MnFe} 2 \mathrm{O} 4$ and supported on activated carbon for glyphosate adsorption in fixed bed column. Process Safety and Environmental Protection, v. 123, n., p. 59-71, 2019. https://doi.org/10.1016/j.psep.2018.12.027 
MAYAKADUWA, S. S.; KUMARATHILAKA, P.; HERATH, I.; AHMAD, M.; AL-WABEL, M.; OK, Y. S.; USMAN, A.; ABDULJABBAR, A.; VITHANAGE, M. Equilibrium and kinetic mechanisms of woody biochar on aqueous glyphosate removal. Chemosphere, v. 144, p. 2516-2521, 2015. https://doi.org/10.1016/j.chemosphere.2015.07.080

MOHAN, D.; SARSWAT, A.; SINGH, V. K.; ALEXANDRE-FRANCO, M.; PITTMAN JR, C. U. Development of magnetic activated carbon from almond shells for trinitrophenol removal from water. Chemical Engineering Journal, v. 172, n. 2-3, p. 1111-1125, 2011. https://doi.org/10.1016/j.cej.2011.06.054

MOHSEN NOUROUZI, M.; CHUAH, T. G.; CHOONG, T. S. Y. Adsorption of glyphosate onto activated carbon derived from waste newspaper. Desalination and Water Treatment, v. 24, n. 1-3, p. 321-326, 2010. https://doi.org/10.5004/dwt.2010.1461

MONDAL, P.; MOHANTY, B.; MAJUMDER, C. B. Treatment of simulated arsenic contaminated groundwater using $\mathrm{GAC}-\mathrm{Cu}$ in batch reactor: Optimization of process parameters. The Canadian Journal of Chemical Engineering, v. 87, n. 5, p. 766-778, 2009. https://doi.org/10.1002/cjce.20214

MYERS, J. P.; ANTONIOU, M. N.; BLUMBERG, B.; CARROLL, L.; COLBORN, T.; EVERETT, L. G.; HANSEN, M.; LANDRIGAN, P. J.; LANPHEAR, B. P.; MESNAGE, R.; VANDENBERG, L. N.; VOM SAAL, F. S.; WELSHONS, W. V.; BENBROOK, C. M. Concerns over the use of glyphosate-based herbicides and risks associated with exposures: a consensus statement. Environmental Health, v. 15, n. 1, p. 1-13, 2016. https://doi.org/10.1186/s12940-016-0117-0

QU, G. Z.; LU, N.; LI, J.; WU, Y.; LI, G. F.; LI, D. Simultaneous pentachlorophenol decomposition and granular activated carbon regeneration assisted by dielectric barrier discharge plasma. Journal of Hazardous Materials, v. 172, n. 1, p. 472-478, 2009. https://doi.org/10.1016/j.carbon.2003.12.032

SALVESTRINI, S.; LEONE, V.; IOVINO, P.; CANZANO, S.; CAPASSO, S. Considerations about the correct evaluation of sorption thermodynamic parameters from equilibrium isotherms. The Journal of Chemical Thermodynamics, v. 68, p. 310-316, 2014. https://doi.org/10.1016/j.jct.2013.09.013

SHAH, I.; ADNAN, R.; WAN NGAH, W. S.; MOHAMED, N. Iron Impregnated Activated Carbon as an Efficient Adsorbent for the Removal of Methylene Blue: Regeneration and Kinetics Studies. PLoS One, v. 10, n. 4, p. e0122603, 2015. https://doi.org/10.1371/journal.pone.0122603

SILVA-MEDEIROS, F. V.; CONSOLIN-FILHO, N.; XAVIER DE LIMA, M.; BAZZO, F. P.; BARROS, M. A. S. D.; BERGAMASCO, R.; TAVARES, C. R. G. Kinetics and thermodynamics studies of silver ions adsorption onto coconut shell activated carbon. $\begin{array}{lllllll}\text { Environmental Technology, } & \text { v., } & \text { n., } & \text { p. } & 1-7,\end{array}$ https://doi.org/10.1080/09593330.2016.1176076

THAMILARASU, P.; KARUNAKARAN, K. Kinetic, equilibrium and thermodynamic studies on removal of Cr (VI) by activated carbon prepared from Ricinus communis seed shell. The Canadian Journal of Chemical Engineering, v. 91, n. 1, p. 9-18, 2013. https://doi.org/10.1002/cjce.20675 
THOMMES, M.; KANEKO, K.; NEIMARK ALEXANDER, V.; OLIVIER JAMES, P.; RODRIGUEZ-REINOSO, F.; ROUQUEROL, J.; SING KENNETH, S. W. Physisorption of gases, with special reference to the evaluation of surface area and pore size distribution (IUPAC Technical Report). Pure and Applied Chemistry, v. 87, n. 9-10, p. 1051-1069, 2015. https://doi.org/10.1515/pac-2014-1117

WAIMAN, C. V.; AVENA, M. J.; GARRIDO, M.; FERNÁNDEZ BAND, B.; ZANINI, G. P. A simple and rapid spectrophotometric method to quantify the herbicide glyphosate in aqueous media. Application to adsorption isotherms on soils and goethite. Geoderma, v. 170, n., p. 154-158, 2012. https://doi.org/10.1016/j.geoderma.2011.11.027

YAMAGUCHI, N. U.; BERGAMASCO, R.; HAMOUDI, S. Magnetic MnFe2O4-graphene hybrid composite for efficient removal of glyphosate from water. Chemical Engineering Journal, v. 295, p. 391-402, 2016. https://doi.org/10.1016/j.cej.2016.03.051

ZHOU, C. R.; LI, G. P.; JIANG, D. G. Study on behavior of alkalescent fiber FFA-1 adsorbing glyphosate from production wastewater of glyphosate. Fluid Phase Equilibria, v. 362, n. 0, p. 69-73, 2014. https://doi.org/10.1016/j.fluid.2013.09.002 